\title{
Malaria in gold-mining areas in Colombia
}

\author{
Angélica Castellanos' ${ }^{1}$ Pablo Chaparro-Narváez², Cristhian David Morales-Plaza ${ }^{3}$, \\ Alberto Alzate ${ }^{1}$, Julio Padilla ${ }^{4}$, Myriam Arévalo ${ }^{1,5}$, Sócrates Herrera ${ }^{1,3} /+$ \\ ${ }^{1}$ Malaria Vaccine and Drug Development Centre, Cali, Colombia ${ }^{2}$ National Institute of Health of Colombia, Bogotá, Colombia \\ ${ }^{3}$ Caucaseco Scientific Research Centre, Cali, Colombia ${ }^{4}$ Ministry of Health and Social Protection, Bogotá, Colombia \\ ${ }^{5}$ Universidad del Valle, Faculty of Health, Cali, Colombia
}

Gold-mining may play an important role in the maintenance of malaria worldwide. Gold-mining, mostly illegal, has significantly expanded in Colombia during the last decade in areas with limited health care and disease prevention. We report a descriptive study that was carried out to determine the malaria prevalence in gold-mining areas of Colombia, using data from the public health surveillance system (National Health Institute) during the period 20102013. Gold-mining was more prevalent in the departments of Antioquia, Córdoba, Bolivar, Chocó, Nariño, Cauca, and Valle, which contributed 89.3\% (270,753 cases) of the national malaria incidence from 2010-2013 and 31.6\% of malaria cases were from mining areas. Mining regions, such as El Bagre, Zaragoza, and Segovia, in Antioquia, Puerto Libertador and Montelibano, in Córdoba, and Buenaventura, in Valle del Cauca, were the most endemic areas. The annual parasite index (API) correlated with gold production $\left(R^{2} 0.82, p<0.0001\right)$; for every $100 \mathrm{~kg}$ of gold produced, the API increased by 0.54 cases per 1,000 inhabitants. Lack of malaria control activities, together with high migration and proliferation of mosquito breeding sites, contribute to malaria in gold-mining regions. Specific control activities must be introduced to control this significant source of malaria in Colombia.

Key words: mining - malaria - Plasmodium vivax - Plasmodium falciparum - gold

Mining has historically played an important role in the expansion and creation of many productive human settlements and to the national economy of mineral rich countries, but simultaneously it has led to an increase in malaria transmission in mining areas (Knoblauch et al. 2014). African and Asian countries, such as Ghana, South Africa, and Papua New Guinea (PNG), report an important percentage of malaria cases originating in gold-mining areas. Likewise in the American continent, Brazil, Colombia, Venezuela, Suriname, and Peru are countries with significant gold extraction associated with high malaria prevalence (Asante et al. 2011, da Silva-Nunes et al. 2012, Ferreira et al. 2012, Mitjà et al. 2013, Parker et al. 2013), which presents mainly as asymptomatic cases and in age groups involved in mining (de Andrade et al. 1995, da Silva-Nunes et al. 2012).

In countries like Ghana, the overall malaria prevalence was $22.8 \%$ in 2006/2007, with $~ 98 \%$ in mining areas that were predominantly Plasmodium falciparum infections (Asante et al. 2011), meanwhile in PNG (Lihir Island) Plasmodium vivax was more prevalent (57\%) in 2006-2011, with a small number of Plasmodium malariae cases $(<3 \%)$ (Mitjà et al. 2013).

doi: 10.1590/0074-02760150382

Financial support: US NIAD/NIH (5U19AI089702), COLCIENCIAS (360-2011, 719-2013)

+ Corresponding author: sherrera@inmuno.org

Received 7 October 2015

Accepted 19 November 2015
Most malaria cases in Brazil come from rural areas related to gold-mining in the Amazon Region, where $52 \%$ of the cases are caused by $P$. vivax, $30 \%$ by $P$. falciparum, and the rest are mix infections and $P$. malariae (de Oliveira et al. 2013); the state of Mato Grosso gold-mining contributed a significant number of cases. In 1992, the annual parasite index (API) was 96.1 per 1,000 inhabitants, but between 1993-2002 it decreased to 2.7 cases per 1,000 inhabitants (Ferreira et al. 2012) due to aggressive active case detection (ACD) implemented by the Brazilian government.

In Peru and Suriname the contribution of mining to malaria prevalence appears to be much lower (3-7\%) (Villegas et al. 2010, da Silva-Nunes et al. 2012, Parker et al. 2013). In the Amazon regions of Peru, Guyana, and Suriname (Guyana Shield) there has been an increase in malaria transmission mainly in informal mining camps due to the lack of opportune diagnosis, availability, and poor quality of antimalarials (Parker et al. 2013, Pribluda et al. 2014).

In Suriname, $66 \%$ of the miner population are Brazilian immigrants (Adhin et al. 2014) and malaria transmission decreased from 14,403 in 2003 to 1,371 in 2009 due to the introduction of artemisinin combination treatment. Gold miners are now the only remaining population that is vulnerable to malaria (Hiwat et al. 2012, Breeveld et al. 2012).

In Colombia mining has for centuries offered the only means of subsistence to some populations, particularly in areas with little presence of the State (Defensoría del Pueblo de Colombia 2010, Semana 2015). However, the Colombian mining industry has grown quickly during the past decade, mostly due to government policies which have favoured foreign investment in mining (PwC 2012), but also because there has been a rapid proliferation of illegal mines (the majority of gold mines are believed to be illegal) (Güiza \& Aristizabal 
TABLE I

Gold-mining district (GMD)

Mining district

(department) Municipalities

Frontino

(Antioquia)

Northeat Antioqueño

(Antioquia)

Santa Rosa

(Bolívar)

San Martín de Loba

(Bolívar)

Montelíbano

(Córdoba)

Minero Istmina

(Chocó)

Costa Pacífica

(Cauca y Valle)

Costa Pacífica Sur

(Nariño)

La Llanada

(Nariño)

Mercaderes

(Cauca and El Tambo Nariño)
Carmen de Atrato $^{a}$, Buriticá, Frontino, Abriaquí, Urrao, Dabeiba, Anzá, Mutatá

Amalfi, El Bagre, Segovia, Zaragoza, Remedios, San Roque

Santa Rosa del Sur, Simití, San Pablo

San Jacinto de Achí, Tiquisio, Morales, San Martín de Loba

Buenavista, Planeta Rica, Pueblo Nuevo, La Apartada, Puerto Libertador, Montelíbano

Itsmina, Condoto, Tadó, Sipí, Bagadó

López de Micay, Guapi, Timbiquí, Buenaventura

Barbacoas, Santa Barbara (Iscuandé), Magui Payan

La Llanada, Santa Cruz, Los Andes (Sotomayor), Cumbitara, Samaniego, Mallama (Piedrancha)

Bolívar, Tambo

$a$ : municipality belonging to the department of Chocó. Description of 47 municipalities that belong to 10 rural areas defined as GMD and their departments, which represent a region with mostly malaria endemic areas. Source: UPME (2005).

2013). An important example of illegal mining is that of Segovia and Remedios (department of Antioquia), one of the most productive districts, where 348 units of gold-mining have been reported, of which only 14 were legal (MINMINAS 2011, INDEPAZ 2013). Although there is no evidence of an association between malaria and the legal mining activities, it could be presumed that legal mining is more environment-friendly with less artificially man-made mosquito breeding sites. Colombia has a great diversity of Anopheles mosquitoes, several of which are either confirmed or suspected malaria vectors. This, together with substantial migration that is frequently induced by mining activities, favours the circulation of malaria infected individuals through mining districts. Moreover, anopheles mosquitoes breed in a great variety of different conditions and adapt to local environmental characteristics such as altitude, climate, weekly rainfall intensity (which influences larval abundance), and land use which may create temporary or permanent man-made habitats in open sky gold-mining. These conditions can significantly impact the phenology and population dynamics of mosquito larvae populations and indirectly affect the dynamics of mosquitoborne diseases (Imbahale et al. 2011). Additionally, the lack of health promotion and prevention measures, the ignorance of such measures by miners, the proximity of their accommodation, known as gold-mining huts, and subsequent migration of workers to other areas, are all factors contributing to the spread of disease, particularly malaria. In malaria endemic communities, a significant percentage $(5-15 \%)$ of the population usually harbour malaria infections without showing clinical symptoms (Vallejo et al. 2015). These individuals represent a pool of parasites for malaria transmission and thus perpetuate its spread (Moreno et al. 2007, 2009, da Silva-Nunes et al. 2012). Importantly, gold production has been reported to closely correlate with malaria burden. In a previous study it was estimated that for every $100 \mathrm{~kg}$ of gold production the API in mining areas would increase by $0.37 / 1,000$ inhabitants, and the annual incidence rates between 160-260 cases/1,000 inhabitants (Duarte \& Fontes 2002). The aim of this study was to assess the current malaria situation in Colombia in regions with gold-mining activities and the correlation between gold production and malaria incidence.

\section{MATERIALS AND METHODS}

Study design - A descriptive and retrospective study of malaria prevalence in mining areas was carried out based on official information from mining districts, that included 47 endemic municipalities of Antioquia, Bolívar, Córdoba, Chocó, Valle del Cauca, and Nariño departments from 2010-2013 (Table I).

Data sources - Data was obtained from sources such as the official national surveillance system [National Health Institute (SIVIGILA)], reports from the Ministry 

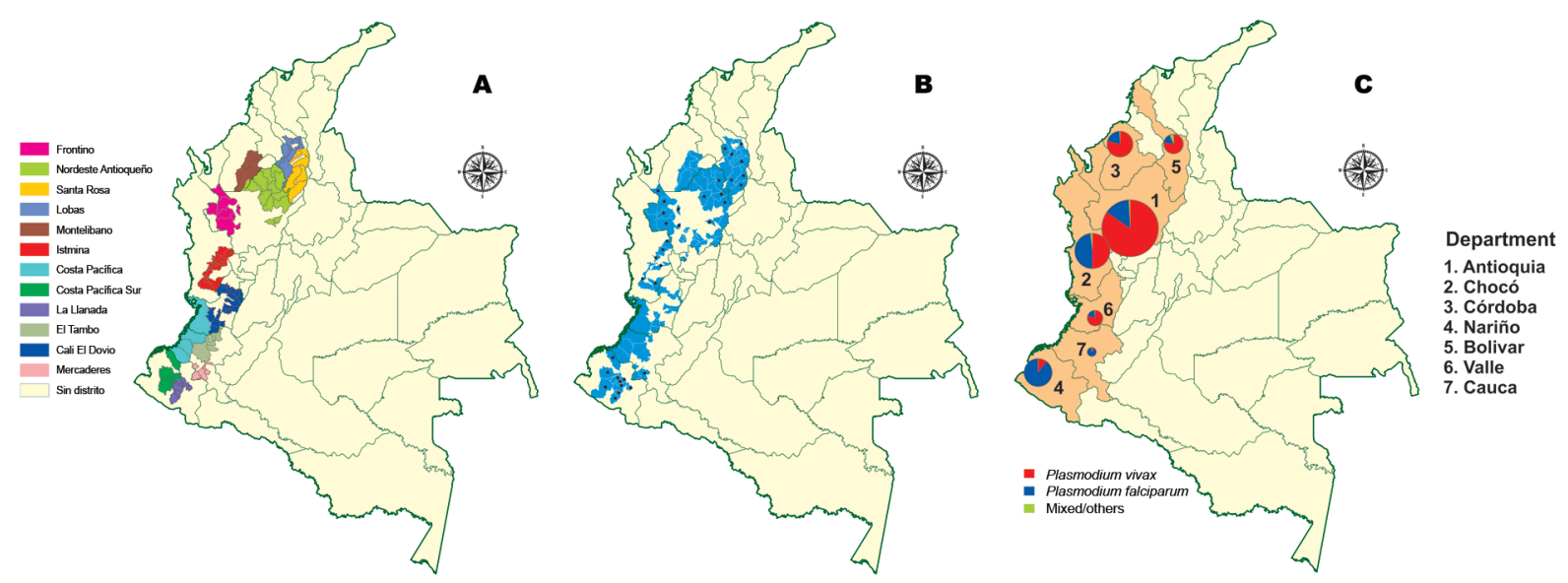

Fig. 1A: gold-mining distribution in malaria endemic areas in Colombia. Name and geographic gold-mining districts (GMD) distribution in Colombia. Source: modified from simco.gov.co/Simco/Portals/0/mapaDistritosMineroscolombia2008.pdf; B: gold-mining production units or municipalities (spot) by GMD. Source: modified from Cuales son los distritos mineros de Colombia? (simco.gov.co/simco/Politicasdelsector/ MejoramientodelaProductividadyCompetitividad/Gesti\%C3\%B3ndelosDistritosMineros/tabid/86/Default.aspx); C: total morbidity of malaria distribution in Colombia by parasite species in 2010-2013.

of Mines and Energy, the Colombian Mining Information System, and the Office of the Ombudsman (Defensoría del Pueblo de Colombia 2010).

Mining districts - "Mining districts" denote areas where mining is performed according to the rules and regulations established by local miners. There are no limits to their territory and their boundaries can change. Ten rural mining districts were selected from departments with the highest gold production. All municipalities were located on alluvial areas or had other environmental factors that promoted ecological niches for the development of malaria vectors (Fig. 1A).

The study population included 1,250 Afro-Colombian communities, with an estimated population of $\sim 270,000$ people and various indigenous groups that formed approximately $4-5 \%$ of the total population. These regions have extreme poverty according to national standards, and have the worst national social and economic indicators.

Data analyses - An Excel database was designed and validated to store the collected information. Epidemiological and mining variables defined for the study were: number of total cases of malaria from 47 municipalities in 10 gold-mining districts (GMD), parasite species, population at risk, annual gold production in towns, and mining districts, over a study period from 2010-2013. The API was calculated using the total number of malaria cases in each municipality and the population at risk for each year in the study period and was reported per 1,000 inhabitants. Statistical tests were performed to look for correlation between annual gold productions in Colombia (estimated in tons) APIs in different mining districts. Potential malaria vectors described here are based on published studies (Montoya-Lerma et al. 2011). Image files of maps in Portable Network Graphics format were used as a data source to create new maps. These were superimposed using GNU Image Manipu- lation Program v.2.8.14 (an open-source raster graphics editor used for image retouching and editing).

Databases were refined according to the recommendations of the monitoring system (SIVIGILA) that included address, validation rules, variable code, date of service, type identification, identification number, primary data generating units and information units, which permitted assessment of duplicate cases. A plan of analysis of the variables was established to calculate absolute and relative frequencies and perform univariate analysis, bivariate correlation, or R square $\left(\mathrm{R}^{2}\right)$ between gold production (ton/year/ GMD) and API with statistical significance tests. Statistical analyses were performed using a database on Excel 2013 and PRISMA GraphPad Prism v.6.01.

\section{RESULTS}

Mining districts in Colombia - According to the classification by the Unit of Planning of Mining and Energy in Colombia, the departments with highest gold production are Antioquia, Córdoba, Bolívar, Chocó, Nariño, Cauca, and Valle, which contributed to $89.3 \%$ (270,753 cases) of the national malaria incidence from 2010-2013, of which $31.6 \%$ came from mining areas (Fig. 1A-C). The 2011 census of mining activities in Colombia reported 4,134 gold mines and only 550 had official owner-titles. Of the 4,134 mines, 2,976 (72\%) were located on the flank of the western mountains in the departments of Antioquia, Bolívar, and Chocó (Fig. 1B). The gold mines below this range in the Pacific lowlands of Valle del Cauca and Nariño are mostly illegal.

Malaria in gold-mining areas of Colombia - During the study period, there was a decreasing trend in malaria in Colombia from $\sim 117,000$ cases in 2010, with an API of $11.5 / 1,000$ inhabitants, to $\sim 60,000$ in 2013 , with an API of 4.95/1,000 inhabitants. In this period there was a reduction in malaria incidence of $\sim 51.3 \%$ (Table II). This 


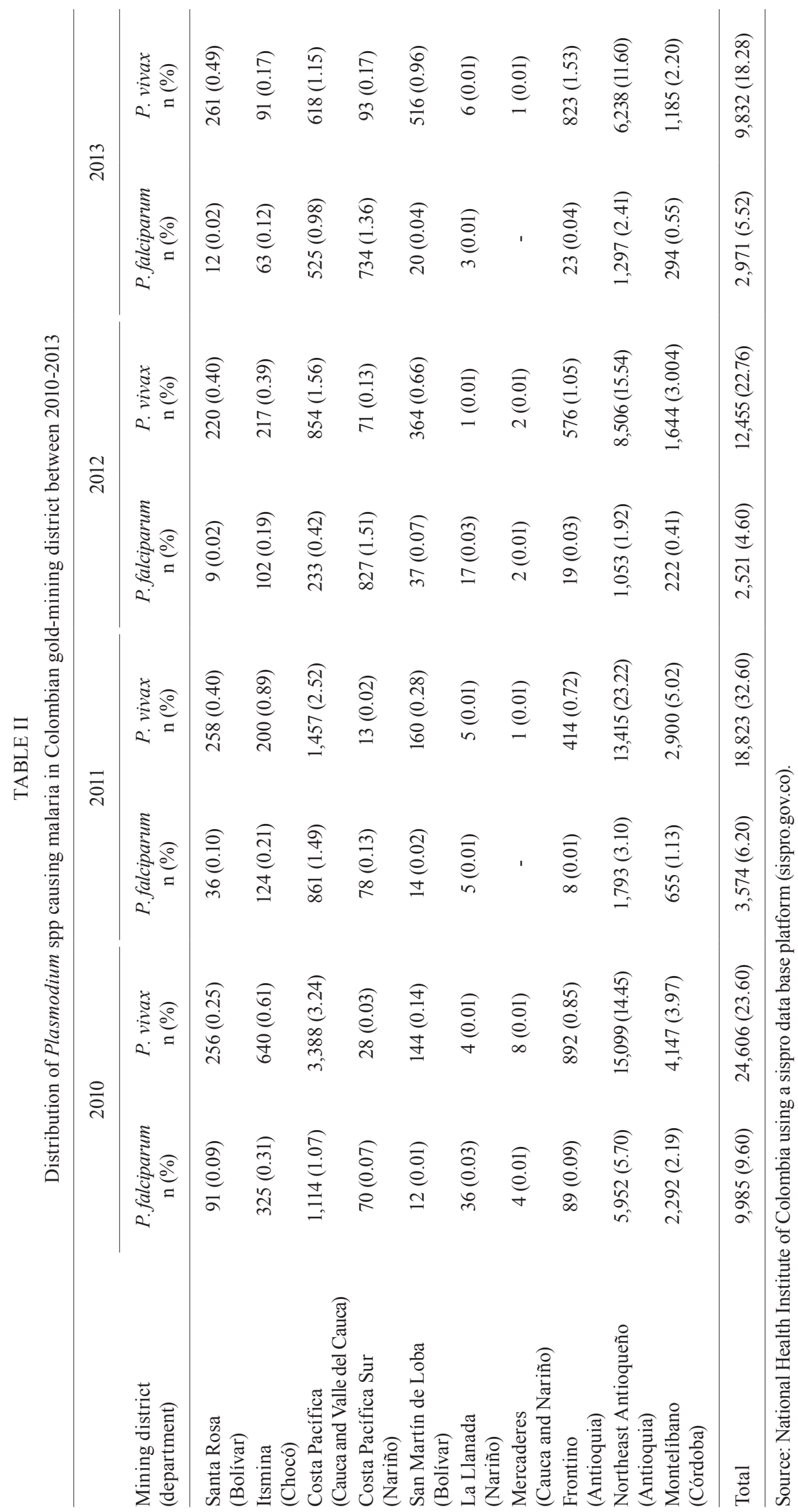


TABLE III

Gold production, malaria cases, and annual parasite index (API) on gold-mining district

\begin{tabular}{|c|c|c|c|c|c|c|c|c|c|c|c|c|}
\hline \multirow[b]{2}{*}{$\begin{array}{l}\text { Mining district } \\
\text { (department) }\end{array}$} & \multicolumn{3}{|c|}{2010} & \multicolumn{3}{|c|}{2011} & \multicolumn{3}{|c|}{2012} & \multicolumn{3}{|c|}{2013} \\
\hline & $\begin{array}{l}\text { Cases } \\
\text { (n) }\end{array}$ & $\begin{array}{l}\text { Gold } \\
\text { (ton) }\end{array}$ & $\begin{array}{c}\text { API } \\
(1,000 / h)\end{array}$ & $\begin{array}{l}\text { Cases } \\
\text { (n) }\end{array}$ & $\begin{array}{l}\text { Gold } \\
\text { (ton) }\end{array}$ & $\begin{array}{c}\text { API } \\
(1,000 / h)\end{array}$ & $\begin{array}{l}\text { Cases } \\
\text { (n) }\end{array}$ & $\begin{array}{l}\text { Gold } \\
\text { (ton) }\end{array}$ & $\begin{array}{c}\text { API } \\
(1,000 / h)\end{array}$ & $\begin{array}{l}\text { Cases } \\
\text { (n) }\end{array}$ & $\begin{array}{l}\text { Gold } \\
\text { (ton) }\end{array}$ & $\begin{array}{c}\text { API } \\
(1,000 / h)\end{array}$ \\
\hline $\begin{array}{l}\text { Santa Rosa } \\
\text { (Bolívar) }\end{array}$ & 422 & 6.4 & 9.64 & 336 & 6.9 & 9.64 & 248 & 7.4 & 7.18 & 277 & 7.9 & 8.09 \\
\hline $\begin{array}{l}\text { Itsmina } \\
\text { (Chocó) }\end{array}$ & 986 & 1.6 & 4.81 & 333 & 1.6 & 4.81 & 328 & 1.6 & 4.70 & 156 & 1.6 & 2.22 \\
\hline $\begin{array}{l}\text { Costa Pacífica } \\
\text { (Cauca and Valle del Cauca) }\end{array}$ & 4,539 & - & 5.29 & 2,330 & - & 5.29 & 1,096 & - & 2.45 & 1,157 & - & 2.54 \\
\hline $\begin{array}{l}\text { Costa Pacífica Sur } \\
\text { (Nariño) }\end{array}$ & 98 & 0.4 & 1.31 & 91 & 0.4 & 1.31 & 901 & 0.4 & 12.73 & 827 & 0.4 & 11.46 \\
\hline $\begin{array}{l}\text { Distrito San Martín de Loba } \\
\text { (Bolívar) }\end{array}$ & 189 & 1.4 & 4.47 & 179 & 1.6 & 4.47 & 426 & 1.8 & 10.52 & 541 & 2 & 13.21 \\
\hline $\begin{array}{l}\text { Distrito La Llanada } \\
\text { (Nariño) }\end{array}$ & 41 & 0.8 & 0.05 & 10 & 0.9 & 0.12 & 18 & 1.0 & 0.21 & 9 & 1.1 & 0.10 \\
\hline $\begin{array}{l}\text { Distrito Mercaderes } \\
\text { (Cauca and Nariño) }\end{array}$ & 12 & 0.1 & 0.01 & 1 & 0.1 & 0.01 & 4 & 0.1 & 0.05 & 1 & 0.2 & 0.01 \\
\hline $\begin{array}{l}\text { Frontino } \\
\text { (Antioquia) }\end{array}$ & 981 & 0.4 & 4.86 & 424 & 0.4 & 4.86 & 599 & 0.4 & 6.83 & 850 & 0.5 & 9.65 \\
\hline $\begin{array}{l}\text { Nordeste Antioqueño } \\
\text { (Antioquia) }\end{array}$ & 21,242 & 23.2 & 182.63 & 15,305 & 29.1 & 182.63 & 9,612 & 29.9 & 113.43 & 7,589 & 28.6 & 88.59 \\
\hline $\begin{array}{l}\text { Montelíbano } \\
\text { (Córdoba) }\end{array}$ & 6,493 & 3.9 & 20.18 & 3,583 & 3.9 & 20.18 & 1,875 & 3.9 & 9.78 & 1,494 & 3.3 & 8.08 \\
\hline Total & 35,003 & 38.2 & 19.37 & 22,592 & 44.9 & 19.37 & 15,107 & 46.5 & 12.67 & 12,901 & 45.6 & 10.77 \\
\hline
\end{tabular}

Source: INCOPLAN SA (2011).

trend was also observed in the mining regions with a few exceptions, including the districts of San Martín de Loba (Bolívar) and South Pacific Coast (Nariño), where malaria prevalence has been stable or has increased over the same period (Table II). However, at department level, in 2012-2013 the departments of Antioquia and Chocó had the highest API of greater than 20/1,000 inhabitants, which were followed by Nariño, with an API of $10.1 / 1,000$ inhabitants. In 2013, $88.8 \%$ of national cases were reported from Antioquia (39.5\%), Chocó (24.8\%), Córdoba (5.4\%), Nariño (10.1\%), Bolívar (5.8\%), Valle del Cauca $(1.7 \%)$, and Cauca (1.6\%). Most infections $(64.9 \%)$ were caused by $P$. vivax, $33.6 \%$ by $P$. falciparum, and $1.4 \%$ were mixed infections.

Before 2010, the mining districts with the highest APIs were northeast Antioquia, Montelíbano (Córdoba), and Santa Rosa (Bolívar), however since 2013, Antioquia, San Martín de Loba (Bolívar), and the South Pacific Coast have had the highest. Although the API in Colombia has decreased over the last five years, it has increased by more than $50 \%$ in the mining districts of San Martin de Loba, Costa Pacífica South, and northeast regions of Antioquia (Table III).
The highest APIs in the country were found in the municipalities in Antioquia [El Bagre (188.2/1,000), Segovia (137.0/1,000), Zaragoza (99.9/1,000), Remedios $(28.9 / 1,000)$, Mutatá $(25.1 / 1,000)$, and Santa Barbara $(20.1 / 1,000)]$ followed by municipalities in Bolívar [San Jacinto de Achí $(34.4 / 1,000)$ and Tiquisio $(32.0 / 1,000)]$, Córdoba [Puerto Libertador (26.2/1,000)], and Bolívar [Santa Rosa del Sur $(13.1 / 1,000)]$. In contrast, the municipality from the districts of Istmina and Costa Pacífica showed a reduction per 1,000 habitants at risk (Table III).

Despite the recent malaria reduction in most mining districts, they still contribute considerably to the national prevalence (Table II). Correlation analyses indicated that there are two groups of mining districts: those with high gold production methods with large numbers of cases and high APIs, and those with low gold production with a low number of malaria cases reported (Table III).

Although the linear model is not the most appropriate, a $\mathrm{R}^{2}$ determination coefficient of 0.69 indicated that $69 \%$ of the variance in number of cases was explained by goldmining production for the analysed time interval. Adjusting the correlation described by the size of the population at risk terms or API (positive thick smear/1,000 inhabitants) resulted in a correlation of 0.90 where $\mathrm{R}^{2}$ was equal 


\section{Correlation index}

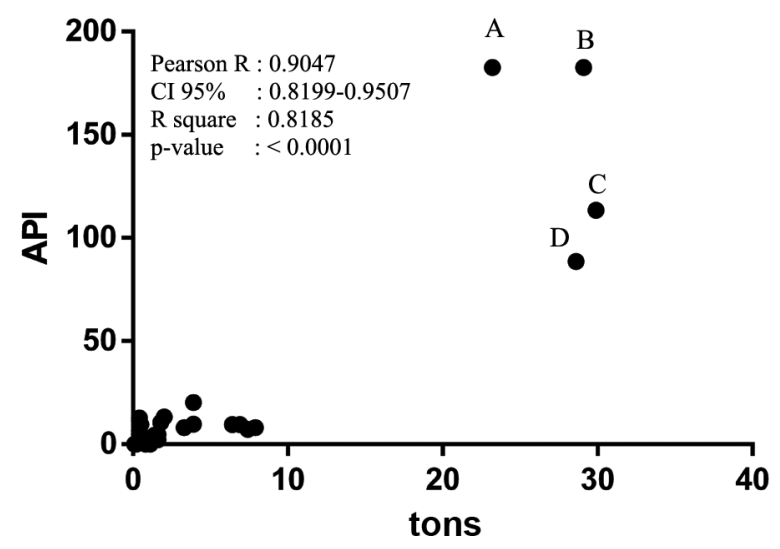

Fig. 2: correlation between annual parasite index (API) and gold-mining district (GMD) production. The increased value of API is explained by tons of gold produced in a GMD (northeast Antioquia) from 2010-2013 (A: 2010; B: 2011; C: 2012; D: 2013). Populations with greater than 50 tons of gold produced had higher risk of malaria infection than those with a lower production. CI: confidence interval.

to 0.81 . This also indicated that the variance of malaria cases in mining areas was explained by the magnitude of the activity and mining per ton (Fig. 2).

Ecological studies found that Anopheles darlingi, Anopheles albimanus, and Anopheles nuñeztovari are the primary malaria vectors in mining areas (MontoyaLerma et al. 2011). In the department Córdoba (municipalities of Montelíbano and Puerto Libertador) $A n$. darlingi and An. nuñeztovari were found infected with P. vivax, (Gutiérrez et al. 2009). Whereas in Chocó An. darlingi was the major vector of $P$. falciparum, however, An. albimanus and An. darlingi were also found infected with P. falciparum and with P. vivax in Chocó and Valle del Cauca (Buenaventura), respectively. Other species are considered to be secondary vectors, such as Anopheles pseudopunctipennis and Anopheles neivai, which are important vectors of human malaria transmission in the Pacific coastal areas of Colombia (Sinka et al. 2010).

\section{DISCUSSION}

In mining districts, the greatest contribution to the national malaria incidence came from the northeast Antioquia district (Antioquia), Pacific Coast district (Chocó), South Pacific Coast and La Llanada districts (Nariño), Montelíbano district (Córdoba), and San Martín de Loba district (Bolívar). Although one third (36\%) of the cases recorded nationally were reported from mining areas, these figures may be underestimated due to population migration and under-recording of malaria cases in areas with illegal mining activity. Nevertheless, in spite of the $50 \%$ reduction in malaria cases between 2010-2013 at national level, this study indicates that mining plays an important role in the maintenance of malaria transmission and imposes an important barrier to malaria elimination, particularly in these regions.
In Colombia, two types of gold mine exploitation related to malaria exist in both legal and illegal mining. One of them is the alluvial type with low rates of malaria cases. In the Colombian Pacific Coast, particularly, miners practice the artisanal mining called barequeo (gold-panning), consisting of traditional manual gold extraction using craft devices (MinAmbiente 2001, Suárez 2011). Barequeo has traditionally been a single-person operation for extracting minerals in small quantities. The other type of mining is a more modern type of gold-mining extraction, for example in Antioquia vetas and "open sky", and was associated with a high number of malaria cases in the study period. This method which uses bulldozers and dredges that have helped mechanise this activity. In addition the clandestine nature of gold-mining, its poor control by authorities has led to poor planning and structure with little legalisation of this activity throughout of the country (Suárez 2011, Güiza \& Aristizabal 2013, Semana 2015). Thus, it was associated with many cases of malaria during the study period.

Although $P$. vivax represents $\sim 68 \%$ of malaria cases recorded nationally, $P$. falciparum presented a high prevalence (46.7\%) in the Pacific Coast mining districts (Fig. 1C). In these districts, most of the population are of African descent and therefore the Duffy negative (Fy-) blood group is highly prevalent. The absence of the Fyblood group affects the rate of $P$. vivax infections, as it offers protection again $P$. vivax blood infection (Herrera 2005). An. darlingi and An. albimanus are commonly in these districts and breed in within "open sky" mining. These two vectors maintain transmission which occurs predominantly in the first part of the night. $P$. vivax infections, which comprise $24-40 \%$ of the total of cases of malaria in mining areas are transmitted by An. darlingi, An albimanus, Anopheles calderoni, and An. nuñeztovari and this has been observed in the Pacific Coast and South Pacific mining districts and the departments of Nariño, Cauca, and Valle del Cauca (Fig. 3) (Gutiérrez et al. 2008, 2009, Montoya-Lerma et al. 2011).

Measures such as reforestation with landscape recovery, vector control activities, better screening for malaria, increased use of repellents, easier access to quality care, and treatment with gametocytocides need to be evaluated for inclusion in malaria elimination programs in mining areas.

ACD offers entire population screening in an area at a given time; however, this method detects only symptomatic cases (Schellenberg et al. 2003, Snow et al. 2005). Due to the high mobilisation of the population in mining areas, the case monitoring process would be interrupted and cases originating in these areas could be labelled as imported cases elsewhere. Thus, ACD is not viable in this context.

Mining populations consist somewhat of malaria susceptible migrants from nonmalaria-endemic areas, who are at great risk of malaria due to the lack of immunity. When this same population returns to their place of origin, they take their parasite infections with them, thus introducing new infections in malaria-naïve communities (Khasnis \& Nettleman 2005, Barbieri \& Sawyer 2007). These populations migrate frequently, and if infected, have the potential to rapidly disseminate different Plasmodium strains to neighbouring regions (Khasnis \& Nettleman 2005). 


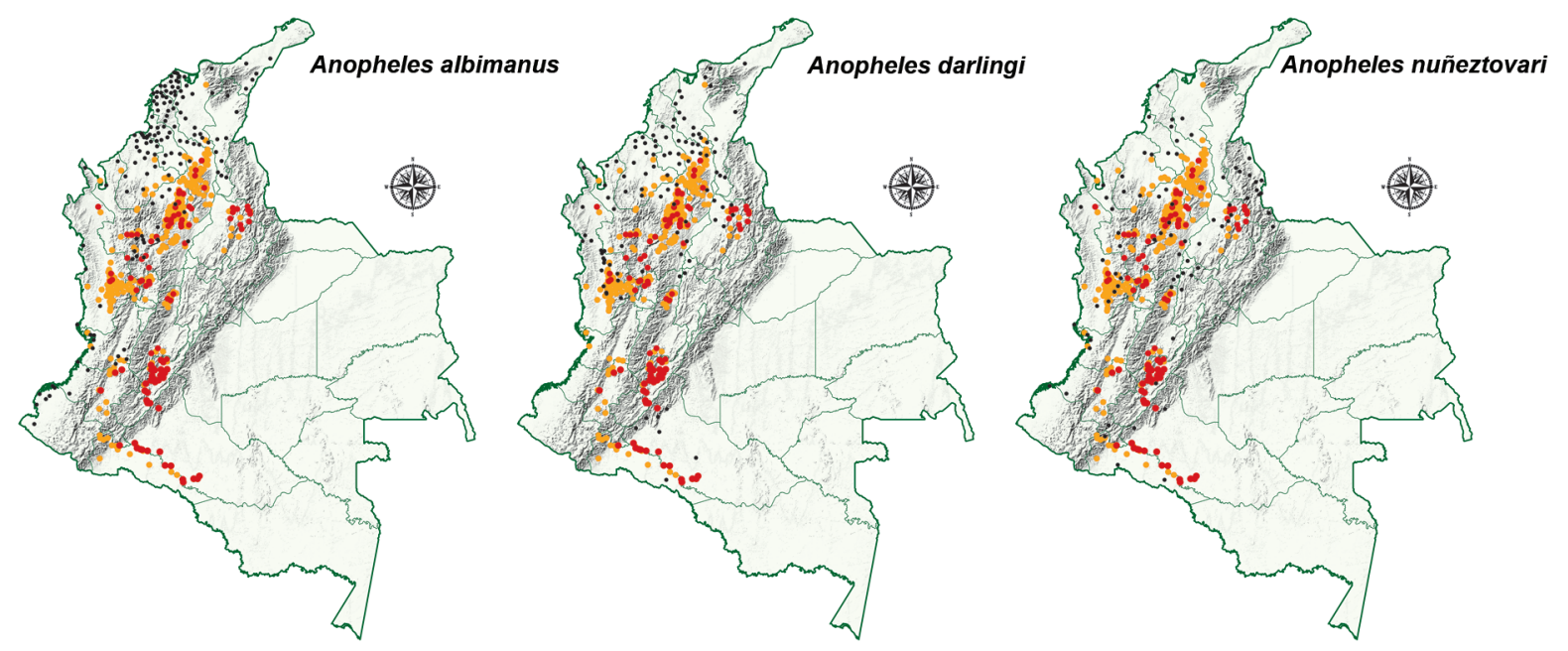

Fig. 3: distribution of Anopheles species in gold-mining areas of Colombia. Illegal gold mines are shown in yellow and legal mines are shown in red. Dark dots show the distribution for the indicated mosquito species in each map. Source: modify from Montoya-Lerma et al. (2011).

Reactive, proactive, and aggressive case detection should be the approach for the detection of asymptomatic cases; however, this methodology would only be viable to reduce transmission rates if more sensitive and specific methods such as polymerase chain reaction-based are used to detect cases with low parasite densities (Macauley 2005, Feachem et al. 2010). The frequency of asymptomatic infections from active searches has not been established to be included in the Colombian National Malaria Control Program. These cases can be very significant in regions with a high frequency of infections reported in the working population whose role in malaria transmission remains unknown as it was evidenced in Buenaventura mining district. Moreover, severe malaria is highly endemic in rural communities that are within close proximity to gold-mining extraction activities as seen in the departments of Chocó and Nariño. In these areas, ongoing studies indicate that the prevalence of complicated malaria cases is $0.5 \%$.

Colombia's annual gold production is expected to increase significantly with the discovery of new mining areas in the Serrania de San Lucas (Bolívar). The resulting association between gold-mining and malaria found in this study underscores an urgent need for improving malaria prevention and control measures in gold-mining areas by government entities and nongovernmental organisations.

This malaria study was conducted to establish the epidemiological parameters based on officials reports from health and mining ministry, in order to review activities to control malaria and other potential vector borne diseases in the area. However, it requires an upgrade of the current and actual statistics with a more in-depth study of the socio-cultural, demographic, and ecological characteristics of mining areas in relation to malaria.

In spite of a reduction of $50 \%$ in malaria cases between 2010-2013 in Colombia, a significant proportion of the cases $(36 \%)$ are related to gold-mining activities. The legal and illegal mining areas are located in regions with a high prevalence of malaria, where malaria vectors are also present. Therefore, mining plays an important role in the maintenance of malaria transmission and is an important barrier to malaria elimination in this region. Even though malaria is decreasing in some nonmining endemic departments, it is increasing in the mining districts, such as Costa Pacífica Sur, in Nariño, and San Martín de Loba, in Bolívar. Aggressive case detection followed by prompt treatment is urgently required to diminish the negative influence of mining regions on malaria transmission. In departments with the highest gold-mining production units, Antioquia, Bolívar, Córdoba, and Chocó, elimination strategies should focus specifically on gold-mining areas.

\section{ACKNOWLEDGEMENTS}

To Yoldy Benavides and María Isabel Arce, for helping with statistical analyses, to Álvaro Álvarez, for map edition, to the ICEMR, Latin American Center for Malaria Research and Control, and the Multidisciplinary Research Network, for the Prevention and Control of Vector-Borne Diseases (Red-ETV), for supporting this work.

\section{REFERENCES}

Adhin MR, Labadie-Bracho M, Vreden S 2014. Gold mining areas in Suriname: reservoirs of malaria resistance? Infect Drug Resist 7: 111-116.

Asante KP, Zandoh C, Dery DB, Brown C, Adjei G, Antwi-Dadzie Y, Adjuik M, Tchum K, Dosoo D, Amenga-Etego S, Mensah C, Owusu-Sekyere KB, Anderson C, Krieger G, Owusu-Agyei S 2011. Malaria epidemiology in the Ahafo area of Ghana. Malar J 10: 211-225.

Barbieri AF, Sawyer DO 2007. Heterogeneity of malaria prevalence in alluvial gold-mining areas in northern Mato Grosso state, Brazil. Cad Saude Publica 23: 2878-2886.

Breeveld FJ, Vreden SG, Grobusch MP 2012. History of malaria research and its contribution to the malaria control success in Suriname: a review. Malar J 11: 95-102.

da Silva-Nunes M, Moreno M, Conn JE, Gamboa D, Abeles S, Vinetz JM, Ferreira MU 2012. Amazonian malaria: asymptomatic human reservoirs, diagnostic challenges, environmentally driven changes in mosquito vector populations, and the mandate for sustainable control strategies. Acta Trop 121: 281-291. 
de Andrade AL, Martelli CM, Oliveira RM, Arias JR, Zicker F, Pang L 1995. High prevalence of asymptomatic malaria in gold-mining areas in Brazil. Clin Infect Dis 2: 475.

de Oliveira EC, dos Santos ES, Zeilhofer P, Souza-Santos R, Atanaka-Santos M 2013. Geographic information systems and logistic regression for high-resolution malaria risk mapping in a rural settlement of the southern Brazilian Amazon. Malar J 12: 420-429.

Defensoría del Pueblo de Colombia 2010. La minería de hecho en Colombia. Available from: responsiblemines.org/attachments/231 mineria-de-hecho-en-colombia-dic-2010.pdf?phpMyAdmin$=$ cde87b62947d46938306cld6ab7a0420.

Duarte EC, Fontes CJ 2002. Association between reported annual gold-mining extraction and incidence of malaria in Mato Grosso-Brazil, 1985-1996. Rev Soc Bras Med Trop 35: 665-668.

Feachem RG, Phillips AA, Hwang J, Cotter C, Wielgosz B, Greenwood BM, Sabot O, Rodriguez MH, Abeyasinghe RR, Ghebreyesus TA, Snow RW 2010. Shrinking the malaria map: progress and prospects. Lancet 376: 1566-1578.

Ferreira IM, Yokoo EM, Souza-Santos R, Galvão ND, Atanaka-Santos M 2012. Factors associated with the incidence of malaria in settlement areas in the district of Juruena, Mato Grosso state, Brazil. Cien Saude Colet 17: 2415-2424.

Güiza L, Aristizabal JD 2013. Mercury and gold-mining in Colombia: a failed state. Univ Scie (Bogota) 18: 33-49.

Gutiérrez LA, González JJ, Gómez GF, Castro MI, Rosero DA, Luckhart S, Conn JE, Correa MM 2009. Species composition and natural infectivity of anthropophilic Anopheles (Diptera: Culicidae) in the states of Córdoba and Antioquia, northwestern Colombia. Mem Inst Oswaldo Cruz 104: 1117-1124.

Gutiérrez LA, Naranjo N, Jaramillo LM, Muskus C, Luckhart S, Conn JE, Correa MM 2008. Natural infectivity of Anopheles species from the Pacific and Atlantic regions of Colombia. Acta Trop 107: 99-105.

Herrera S, Gómez A, Vera O, Vergara J, Valderrama-Aguirre A, Maestre A, Méndez F, Wang R, Chitnis CE, Yazdani SS, ArévaloHerrera M 2005. Antibody response to Plasmodium vivax antigens in Fy-negative individuals from the Colombian Pacific Coast. Am J Trop Med Hyg 73: 44-49.

Hiwat H, Hardjopawiro LS, Takken W, Villegas L 2012. Novel strategies lead to pre-elimination of malaria in previously high-risk areas in Suriname, South America. Malar J 11: 10-22.

INCOPLAN SA 2011. Estudio técnico sectorial, infraestructura de transporte multimodal y de logísticas integradas para el desarrollo dela industria minera en Colombia con énfasis en puertos. Available from: simco.gov.co/LinkClick.aspx?fileticket $=0 \mathrm{CBL}$ MjONx3M=\&tabid=282.

Imbahale SS, Paaijmans KP, Mukabana WR, van Lammeren R, Githeko AK, Takken W 2011. A longitudinal study on Anopheles mosquito larval abundance in distinct geographical and environmental settings in western Kenya. Malar J 10: 81-94.

INDEPAZ - Instituto de Estudios para el Desarrollo y la Paz 2013. Impacto de la minería de hecho en Colombia. Estudios de caso: Quibdó, Istmina, Timbiquí, López de Micay, Guapi, El Charco y Santa Bárbara. Available from: uis.edu.co/webUIS/es/catedraLowMaus/lowMauss13 1/terceraSesion/Impacto\%20de $\% 20$ la $\% 20$ mineria $\% 20$ de $\% 20$ hecho $\% 20$ en $\% 20$ Colombia.pdf.

Khasnis AA, Nettleman MD 2005. Global warming and infectious disease. Arch Med Res 36: 689-696.

Knoblauch AM, Winkler MS, Archer C, Divall MJ, Owuor M, Yapo RM, Yao PA, Utzinger J 2014. The epidemiology of malaria and anaemia in the Bonikro mining area, central Côte d'Ivoire. Malar J 13: 194-203.

Macauley C 2005. Aggressive active case detection: a malaria control strategy based on the Brazilian model. Soc Sci Med 60: 563-573.
MinAmbiente - Ministerio de Ambiente y Desarrollo Sostenible Colombia 2001. Ley 685 de 2001. Available from: minambiente.gov. co/images/normativa/leyes/2001/ley_0685_2001.pdf.

MINMINAS - Ministerio de Minas y Energía de Colombia 2011. Infraestructura de transporte multimodal y de logísticas integradas para el desarrollo de la industria minera en Colombia, con énfasis en puertos. Estudio técnico sectorial. Informe final. Available from: simco. gov.co/LinkClick.aspx?fileticket=0CBLMjONx3M=\&tabid=282.

Mitjà O, Paru R, Selve B, Betuela I, Siba P, de Lazzari E, Bassat Q 2013. Malaria epidemiology in Lihir Island, Papua New Guinea. Malar J 12: 98-103.

Montoya-Lerma J, Solarte YA, Giraldo-Calderón GI, Quiñones ML, Ruiz-López F, Wilkerson RC, González R 2011. Malaria vector species in Colombia - A review. Mem Inst Oswaldo Cruz 106 (Suppl. I): 223-238.

Moreno JE, Rubio-Palis Y, Páez E, Pérez E, Sánchez V 2007. Abundance, biting behaviour, and parous rate of anopheline mosquito species in relation to malaria incidence in gold-mining areas of southern Venezuela. Med Vet Entomol 21: 339-349.

Moreno JE, Rubio-Palis Y, Páez E, Pérez E, Sánchez V, Vaccari E 2009. Malaria entomological inoculation rates in gold-mining areas of southern Venezuela. Mem Inst Oswaldo Cruz 104: 764-768.

Parker BS, Olortegui MP, Yori PP, Escobedo K, Florin D, Pinedo SR, Greffa RC, Vega LC, Ferrucci HR, Pan WK, Chavez CB, Vinetz JM, Kosek M 2013. Hyperendemic malaria transmission in areas of occupation-related travel in the Peruvian Amazon. Malar J 12: 178.

Pribluda VS, Evans 3rd L, Barillas E, Marmion J, Lukulay P, Chang $\mathrm{J}$ 2014. Were medicine quality and pharmaceutical management contributing factors in diminishing artemisinin efficacy in Guyana and Suriname? Malar J 13: 77-82.

Pwc - PricewaterhouseCoopers 2012. Mining in the Americas. Available from: pwc.com/ca/en/industries/mining.html.

Schellenberg DM, Aponte JJ, Kahigwa EA, Mshinda H, Tanner M, Menéndez C, Alonso PL 2003. The incidence of clinical malaria detected by active case detection in children in Ifakara, southern Tanzania. Trans R Soc Trop Med Hyg 97: 647-654.

Semana 2015. El nuevo flagelo que devora a Colombia. Available from: semana.com/nacion/multimedia/la-guerra-contra-lamineria-ilegal-criminal-en-colombia/422834-3.

Sinka ME, Rubio-Palis Y, Manguin S, Patil AP, Temperley WH, Gething PW, Van Boeckel T, Kabaria CW, Harbach RE, Hay SI 2010. The dominant Anopheles vectors of human malaria in the Americas: occurrence data, distribution maps, and bionomic précis. Parasit Vectors 3: 72-98.

Snow RW, Guerra CA, Noor AM, Myint HY, Hay SI 2005. The global distribution of clinical episodes of Plasmodium falciparum malaria. Nature 434: 214-217.

Suárez LG 2011. Perspectiva jurídica de los impactos ambientales sobre los recursos hídricos provocados por la minería en Colombia. Opin Juridi 10: 123-140.

UPME - Unidad de Planeación Minero Energética 2005. Plan de infraestructura de transporte y portuaria para el desarrollo minero en Colombia. Informe final. Módulo 1: caracterización de distritos mineros: exportaciones e infraestructura de transporte, Digitos y Diseños, Bogotá, 120 pp.

Vallejo AF, Chaparro PE, Benavides Y, Álvarez Á, Quintero JP, Padilla J, Arévalo-Herrera M, Herrera S 2015. High prevalence of sub-microscopic infections in Colombia. Malar J 14: 201-208.

Villegas L, Cairo H, Huur A, Vinisi H, Pereira H, Jozuazoon N, Refos F, Summerville S, Hardjopawiro L, Jordaan M, Mitro S, Hiwat H, Alensi C, Malaria Technical Committee 2010. Mass screening and treatment for malaria among gold miners in Suriname. Int J Infect Dis 14: e435. 